Old Dominion University

ODU Digital Commons

2020

\title{
Peer Review in Online Professional Communities to Support Elementary Disciplinary Literacy Planning
}

Jaime Colwell

Old Dominion University, jcolwell@odu.edu

Valerie Taylor

Old Dominion University, vstaylor@odu.edu

Follow this and additional works at: https://digitalcommons.odu.edu/teachinglearning_fac_pubs

Part of the Elementary Education Commons, and the Teacher Education and Professional

Development Commons

\section{Original Publication Citation}

Colwell, J., \& Taylor, V. (2020). Peer review in online professional communities to support elementary disciplinary literacy planning. In Effective Practices in Online Teacher Preparation for Literacy Educators (pp. 107-127). Information Science Reference (Imprint of IGI Global). https://doi.org/10.4018/ 978-1-7998-0206-8.ch006

This Book Chapter is brought to you for free and open access by the Teaching \& Learning at ODU Digital Commons. It has been accepted for inclusion in Teaching \& Learning Faculty Publications by an authorized administrator of ODU Digital Commons. For more information, please contact digitalcommons@odu.edu. 


\title{
Chapter 6 \\ Peer Review in Online Professional Communities to Support Elementary Disciplinary Literacy Planning
}

\author{
Jamie Colwell \\ Old Dominion University, USA \\ Valerie Taylor \\ Old Dominion University, USA
}

\begin{abstract}
This chapter reports the results of a qualitative case study focused on elementary pre-service teachers' perspectives on planning for disciplinary literacy using peer review in an online professional community $(O P C)$. Seven pre-service teachers enrolled in an eight-week asynchronous, online content literacy course served as participants. Results indicated pre-service teachers' valued extended opportunities for reflection in the OPC and appreciated diverse backgrounds and experiences offered by their OPC colleagues. However, perceived challenges remained that are important to consider when incorporating peer review cycles into online asynchronous coursework. This study considers these perspectives in light of designing and planning online coursework in elementary disciplinary literacy.
\end{abstract}

\section{INTRODUCTION}

This chapter focuses on a fully online asynchronous course in a teacher education program and how preservice teachers (PSTs) perceived peer review of elementary disciplinary literacy lesson planning in an Online Professional Community (OPC) to support their planning. The course was required in a hybrid (both face-to-face and online) teacher certification program at large, public research university in the Mid-Atlantic region of the U.S. The focus of the course was to build elementary pre-service teachers' awareness, understanding, and experience with planning for disciplinary literacy in multiple K-5 content

DOI: $10.4018 / 978-1-7998-0206-8 . c h 006$

Copyright $\odot$ 2020, IGI Global. Copying or distributing in print or electronic forms without written permission of IGI Global is prohibited. 
areas. Thus, the culminating assessment for the course were the completion of four lesson cycles for planning disciplinary literacy instruction in K-5 classrooms.

\section{GOAL STATEMENT}

Goal: To support pre-service teachers in planning for elementary disciplinary literacy through peer review in online professional communities. (ILA 2.1)

The use of evidence-based practices (EBP) can have a strong impact on both teachers and students (Maheady, Smith, \& Jabot, 2013). Educators who implement these practices with fidelity feel that they are using interventions grounded in research to support student learning and achievement (Scheeler, Budin, $\&$ Markelz, 2016). Pre-service teachers should be introduced to these practices as students so they are familiar with the techniques before they enter the classroom. Indeed, the International Literacy Association's Standards for the Preparation of Literacy Professionals (2018) mandate that teacher candidates "use foundational knowledge to design, select, critique, adapt, and evaluate evidence-based literacy curricula that meet the needs of all learners." For example, as is the focus of this study, pre-service teachers who are taught to utilize instructional tools and engage in evidence-based practices, such as peer review, to plan disciplinary literacy lessons may be better prepared to teach.

Digital spaces, specifically online professional communities (OPCs), can be used for collaboration and planning of disciplinary literacy lessons and units with pre-service teachers, and peer review may seamlessly fit into these communities due to their peer-centric structure. Educational OPCs are formed when teachers come together either formally or informally in an online space for the purpose of professional learning (Duncan-Howell, 2010). Members of OPCs are encouraged to be both contributors and observers / learners stimulated to engage in joint construction of knowledge, conversation, and review (Lock, 2006). Extending resources and networks of learning and support may increase collaboration and enthusiasm about a topic or lesson while allowing new teachers to step away from the traditional methods in which they may have been previously exposed (Beach, 2012). OPCs are often focused on inquiry and learning, and these online communities may support participants in working together to create inquiry-based lessons (Hobbs \& Corio, 2016), a feature of disciplinary literacy, by incorporating the ability to share URLs and post websites for collaborative planning and instructional feedback (McConnell, Parker, Eberhardt, Koehler, \& Lundeberg, 2012). This research study examines connections between peer review supported in OPCs and ILA Standard 2.1 by considering the role that peer review through online professional communities played in supporting pre-service teachers' planning and design for elementary disciplinary literacy.

\section{REVIEW OF LITERATURE}

\section{Elementary Disciplinary Literacy}

Disciplinary literacy continues to be a topic of increasing importance in literacy education (Moje 2015), and its principles have begun to extend into elementary grades (Shanahan \& Shanahan, 2014). Put broadly, disciplinary literacy consists of the practices and skills required to comprehend and actively participate in the study of a discipline, such as math, science, or history, similarly to that of an expert, such 
as a mathematician, scientist, or historian (Moje, 2008; Shanahan \& Shanahan, 2008; 2014). Although more focus has been given to disciplinary literacy in middle and upper grades, attention is increasing at the elementary grade levels (Brock, Goatley, Raphael, Trost-Shahata, \& Weber, 2014; Shanahan \& Shanahan, 2014). Indeed, more researchers, teachers, and teacher educators have begun to consider how literacy takes on different meanings when considered in particular elementary content areas (Cappello \& Lafferty, 2015; Håland, 2016; Juel, Hebard, Haubner, \& Moran, 2010; Wright \& Gotwals, 2017).

Elementary-level planning typically involves consideration of multiple content areas as teachers move fluidly from one content area to the next in a day's instruction and are responsible for educating students with varying reading abilities in a variety of content areas (Brock et al., 2014). Thus, when preparing pre-service teachers for a literacy perspective, such as disciplinary literacy, teacher educators must provide ample support in the practice of planning, particularly in grade levels where disciplinary literacy is just emerging as a concentration. In an asynchronous online context, OPCs may be one such structure of support where students can interact in an online setting to plan, discuss, and revise lessons focused on elementary disciplinary literacy.

\section{Online Professional Communities and Peer Review}

Online professional communities (OPCs) have become spaces for teachers and pre-service teachers to collaborate, share ideas and provide useful critique regarding instructional practices (Darling-Hammond \& Richardson, 2009). OPCs not only provide platforms for conversation and sharing of ideas, but also as a place for members to evaluate and improve their own work and that of others seeking feedback (Moore $\&$ Teather, 2013). Accordingly, the OPCs in this study were focused on peer review to help PSTs connect, critique, and work to improve instructional planning in disciplinary literacy. OPCs are most common in in-service teacher professional development, but research suggests the potential for incorporating these communities in pre-service teacher education (Colwell \& Hutchison, 2018; Bond, 2013; Wright, 2010).

Wray (2007) explains that, at their core, OPCs are, "teacher learning communities...generally seen as organized opportunities for a group of teacher learners to engage in the understanding, development, and reflection on the practice of teaching and learning" (p. 1141). This conception of OPCs aligned with the goal to support pre-service teachers in planning for disciplinary literacy in elementary grades through peer review in an online course environment. Additionally, research indicates that asynchronous feedback in online environments is a promising tool in peer review (Honeycutt, 2001; Strasma, 2009) and a beneficial learning strategy in preservice teacher education (Boud, Cohen, \& Sampson, 2001).

Thus, the researchers considered the potential of an OPC to structure this process and provide a space for "understanding, development, and reflection" on teaching practices in elementary disciplinary literacy.

OPCs provide a digital space where teachers can collectively generate knowledge and share ideas, creating early experiences with professional development and continuous learning (Bond, 2013; Wright, 2010), an important component of peer review in professional development. Membership in an OPC offers teachers a collaborative forum to discuss the success of a lesson or change in pedagogy in addition to researching and planning disciplinary literacy lessons (Duncan-Howell, 2010). Similarly, active participation in collaborative groups, such as OPCs, allows teachers to find new and creative instructional methods that may not have emerged without the active participation of other individuals (Hobbs \& Corio, 2016). This collaboration enriches the learning process and mimic strategies that are easily transferred into the classroom (Willis \& Cifuentes, 2005). Such experience is enhanced through participation and reflection (Wray, 2007). Sim (2006) suggests that communities of practice, such as 
OPC, allow members to negotiate meaning and make connections through social practice, making it a collaborative community of learning.

This community of learning was considered important to the course in which this study was conducted as pre-service teachers were learning about disciplinary literacy and methods for its integration for the first time and they needed to be supported in planning for this type of literacy instruction. Further, it is important to examine how pre-service teachers perceive planning for elementary disciplinary literacy, as teacher perceptions are critical to future adoption of literacy methods (Anders, Hoffman, \& Duffy, 2000; Richardson, 1996). Although literature has begun to emerge in this area (see Gritter, 2010; Park, 2013; Pytash, 2011), particularly in how online social spaces of learning may affect PSTs' perceptions of disciplinary literacy (Colwell, 2012; 2016; Colwell \& Hutchison, 2018), additional study is required to consider these tools in the context of an online teacher education course with specific focus on PSTs' peer review within an OPC.

\section{METHODS}

The study was organized as a case study (Yin, 2018) to examine the experiences of pre-service teachers who participated in the OPCs. The following research question aligned with the goal presented previously and was used to guide data collection and analysis:

- How do pre-service teachers perceive peer review in online professional communities to support their planning for elementary disciplinary literacy?

\section{Participants}

Seven female pre-service teachers, enrolled in a graduate-level content area literacy course, that had a particular focus on disciplinary literacy, volunteered to participate and comprised the single-case study (Yin, 2018). All participants were working toward initial certification in elementary education. Students were either in their fifth year of a $4+1$ Bachelors program or in their final year of their Master's program for initial certification. The course was a required university course for certification. It did not have a field experience or practicum associated with it. However, all participants had completed field experiences prior to this course and were taking at least one other program course that supported a field experience. Four of the seven participants worked as substitute teachers in local elementary schools. Table 1 provides an overview of the participants (all names are pseudonyms) and delineates their OPC groups.

The content area literacy course was a 14-week online asynchronous course taught by the first author. The course was module-based, with each week focusing on a different learning module that students could work through at their own pace, provided they submitted discussion and reflection assignments by weekly deadlines. Each module focused on topics in foundations of disciplinary literacy (e.g., academic vocabulary, writing, assessment). All modules were released at the outset of the course, so students could work at their own pace, based on their individual schedules.

For most pre-service teachers, the course presented largely new approaches and procedures in elementary literacy instruction. Disciplinary literacy was a new term and focus for these pre-service teachers, and much preparation was necessary at the outset of the course to ground their understandings of literacy particular to each content area that aligned with elementary literacy instruction (Juel, et 
Table 1. Participant Overview

\begin{tabular}{|l|l|l|l|}
\hline \hline \multirow{2}{*}{ Participants \& OPC } & \multicolumn{1}{|c|}{ Program Field Experience } \\
\hline \multirow{4}{*}{ OPC 1 } & Janene & Masters & Program field experience/Substitute teaching \\
\cline { 2 - 4 } & Anna & $4+1$ & Program field experience \\
\cline { 2 - 4 } & Leah & $4+1$ & Program field experience \\
\hline \multirow{3}{*}{ OPC 2 } & Stella & Masters & Program field experience/Substitute teaching \\
\cline { 2 - 4 } & Kirsten & Masters & Program field experience/Substitute teaching \\
\cline { 2 - 4 } & Ellie & Masters & Program field experience \\
\cline { 2 - 4 } & Alyece & Masters & Program field experience/Substitute teaching \\
\hline
\end{tabular}

al., 2010; Shanahan \& Shanahan, 2014). These understandings were assessed through comprehensive planning for literacy in three different disciplines, self-selected by each pre-service teacher. Planning was structured using author-developed lesson cycle templates that promoted in-depth reflection during a six-phase planning process. Once completed, pre-service teachers engaged in peer review of planning in online professional communities (OPCs) to support, provide feedback, and extend thinking about elementary disciplinary literacy instruction.

\section{Context: Lesson Cycles and Peer Review}

At the beginning of the course, PSTs were provided instruction and a practice peer review task in the second course module, prior to completing their first formal peer review with the OPC. Instruction in peer review consisted of two screencasts that PSTs viewed before practicing. The first screencast was of the instructor explaining peer review specific to the peer review rubric (see Table 2). The second screencast presented the instructor modeling peer review, using the peer review rubric, of a blinded completed lesson cycle from a previous semester's class. PSTs were then provided with another completed lesson cycle to review using the peer review rubric. These reviews were submitted to the instructor for feedback.

Participants were required to complete four lesson cycles throughout the semester to structure their planning for elementary disciplinary literacy. The lesson cycles required pre-service teachers to select a disciplinary topic to plan in a six-phase cycle. Appendix A provides the template for the planning cycles used in the present course. The lesson cycle also required pre-service teachers to actively reflect on how they used, or did not use, their peer's feedback in the OPC. To form OPCs for peer review, the researchers created small groups (three to four pre-service teachers per group) on Blackboard, the online platform used by the university in which this study took place, for pre-service teachers to share each of the four drafts of their completed lesson cycles prior to submitting them to the instructor. Blackboard offered grouping features that allowed purposeful selection and placement of pre-service teachers in small groups that were easy to navigate, and each OPC small group was a private space.

The pre-service teachers were provided a peer review rubric, requiring an "unacceptable," proficient," or "exemplary" rating with corresponding open-ended comments, to complete for each of the members in their OPC. The peer review rubric aligned with the final lesson cycle rubric the instructor used to grade each lesson cycle (see Table 2 for peer review rubric and Table 3 for the final lesson cycle rubric).

As each small group consisted of three to four members, each pre-service teacher received two or three completed peer review rubrics from their group members to consider for each of the lesson cycles they 
Table 2. Peer Review Lesson Cycle Rubric

\begin{tabular}{|c|c|c|}
\hline Indicator & Ratings: (Highilight the appropriate rating) & Comments to Peer: \\
\hline $\begin{array}{l}\text { Develop essential questions } \\
\text { that frame and guide instruction } \\
\text { to promote discovery and } \\
\text { inquiry through an open-ended } \\
\text { question. }\end{array}$ & $\begin{array}{l}\text { Unacceptable: The essential question is not open-ended and does not } \\
\text { guide frame instruction to promote discovery or inquiry. } \\
\text { Proficient: The essential question is open-ended and guides } \\
\text { instruction. } \\
\text { Exemplary: The essential question is open-ended to guide instruction } \\
\text { by having students engage in discovery-based or inquiry-based } \\
\text { learning. }\end{array}$ & \\
\hline $\begin{array}{l}\text { Develop goals for } \\
\text { understandings that focus on } \\
\text { what knowledge and skills } \\
\text { students should master and be } \\
\text { able to do. }\end{array}$ & $\begin{array}{l}\text { Unacceptable: Understandings do not focus on big ideas and } \\
\text { important information in disciplinary learning that align with state } \\
\text { standards. } \\
\text { Proficient: Understandings somewhat focus on big ideas and important } \\
\text { information in disciplinary learning that align with state standards. } \\
\text { Exemplary: Understandings focus on big ideas and important } \\
\text { information in disciplinary learning that align with state standards. }\end{array}$ & \\
\hline $\begin{array}{l}\text { Apply performance tasks } \\
\text { as assessments to ensure } \\
\text { students are making progress } \\
\text { toward learning goals and } \\
\text { understandings. }\end{array}$ & $\begin{array}{l}\text { Unacceptable: Tasks described are not performance tasks. } \\
\text { Proficient: Tasks described are performance tasks that somewhat } \\
\text { ensure students are making progress toward learning goals and } \\
\text { understandings. } \\
\text { Exemplary: Tasks described are performance tasks that } \\
\text { ensure students are making progress toward learning goals and } \\
\text { understandings. }\end{array}$ & \\
\hline $\begin{array}{l}\text { Performance tasks provide } \\
\text { opportunities for students to } \\
\text { apply subject matter by: } \\
\text {-analyzing/making inferences } \\
\text {-interpreting \& evaluating or } \\
\text {-synthesizing/ transferring } \\
\text { application of content to new } \\
\text { situations. }\end{array}$ & $\begin{array}{l}\text { Unacceptable: The candidate does not provide opportunities for } \\
\text { student to apply subject matter through performance tasks. } \\
\text { Proficient: The candidate provides an opportunity for students to apply } \\
\text { subject matter through performance tasks. } \\
\text { Exemplary: The candidate provides multiple or differentiated } \\
\text { opportunities for students to apply subject matter through performance } \\
\text { tasks. }\end{array}$ & \\
\hline $\begin{array}{l}\text { Apply content area literacy } \\
\text { strategies before reading to } \\
\text { activate prior knowledge and/or } \\
\text { set purpose for learning, during } \\
\text { learning, and in reflecting on } \\
\text { learning. }\end{array}$ & $\begin{array}{l}\text { Unacceptable: The candidate does not apply content area literacy } \\
\text { strategies. } \\
\text { Proficient: The candidate identifies and applies at least two content } \\
\text { area literacy strategy that supports student understanding. } \\
\text { Exemplary: The candidate identifies and applies several content area } \\
\text { literacy strategies that supports student understanding. }\end{array}$ & \\
\hline
\end{tabular}

submitted. Appendix B provides a sample completed peer review rubric for illustration. A peer review schedule was provided to structure specific dates that each lesson cycle draft should be submitted, when feedback should be provided to each group members, and when responses to group members' feedback should be provided, as these OPCs were asynchronous to align with the course format. The small groups also had a discussion board feature where pre-service teachers could post general comments, questions, or suggestions for one another to consider and were required to do so per course and project guidelines. The OPCs were both structured to ensure active participation among all group members, and open-ended as discussion could take place at any time via the discussion board.

To engage in peer feedback, pre-service teachers completed a draft lesson cycle one week prior to final lesson cycle submissions, and posted it in their OPC. Students were randomly placed, by Blackboard, into their OPC. Each member of the OPC was responsible for reviewing and responding to, using the peer review rubric, each group member's draft cycle. Thus, each group member had to post one draft of their lesson cycle and then provide a completed peer review, using the template, to each of the other group 
Table 3. Final Lesson Cycle Rubric

\begin{tabular}{|c|c|c|c|c|}
\hline Indicator & Developing & Proficient & Exemplary & Total \\
\hline $\begin{array}{l}\text { Develop essential questions } \\
\text { that frame and guide } \\
\text { instruction to promote } \\
\text { discovery and inquiry } \\
\text { through an open-ended } \\
\text { question. }\end{array}$ & $\begin{array}{l}\text { The essential question is } \\
\text { open-ended and guides } \\
\text { instruction, but does not } \\
\text { engage students in discovery- } \\
\text { based or inquiry-based } \\
\text { learning. }\end{array}$ & $\begin{array}{l}\text { The essential question is open- } \\
\text { ended and guides instruction, } \\
\text { and somewhat engage students } \\
\text { in discovery-based or inquiry- } \\
\text { based learning. }\end{array}$ & $\begin{array}{l}\text { The essential question is } \\
\text { open-ended and guides } \\
\text { instruction by having } \\
\text { students engage in } \\
\text { discovery-based or inquiry- } \\
\text { based learning. }\end{array}$ & \\
\hline $\begin{array}{l}\text { Identify appropriate } \\
\text { disciplinary practices that } \\
\text { define and support literacy in } \\
\text { the targeted discipline. }\end{array}$ & $\begin{array}{l}\text { Disciplinary practices are } \\
\text { not defined, cited, nor do } \\
\text { they support literacy in the } \\
\text { targeted discipline. }\end{array}$ & $\begin{array}{l}\text { Disciplinary practices are } \\
\text { defined and cited, but they do } \\
\text { not support, or only minimally } \\
\text { support, literacy in the } \\
\text { targeted discipline. }\end{array}$ & $\begin{array}{l}\text { Disciplinary practices are } \\
\text { defined and cited, and } \\
\text { they support literacy in the } \\
\text { targeted discipline. }\end{array}$ & \\
\hline $\begin{array}{l}\text { Develop goals for } \\
\text { understandings that focus on } \\
\text { what knowledge and skills } \\
\text { students should master and } \\
\text { be able to do. }\end{array}$ & $\begin{array}{l}\text { Understandings have limited } \\
\text { focus on big ideas and } \\
\text { important information in } \\
\text { disciplinary learning that } \\
\text { align with state standards. }\end{array}$ & $\begin{array}{l}\text { Understandings somewhat } \\
\text { focus on big ideas and } \\
\text { important information in } \\
\text { disciplinary learning that align } \\
\text { with state standards. }\end{array}$ & $\begin{array}{l}\text { Understandings focus on } \\
\text { big ideas and important } \\
\text { information in disciplinary } \\
\text { learning that align with state } \\
\text { standards. }\end{array}$ & \\
\hline $\begin{array}{l}\text { Apply performance tasks } \\
\text { as assessments to ensure } \\
\text { students are making progress } \\
\text { toward learning goals and } \\
\text { understandings through } \\
\text { application of disciplinary } \\
\text { matter. }\end{array}$ & $\begin{array}{l}\text { Performance tasks are } \\
\text { described that do not ensure } \\
\text { students are making progress } \\
\text { toward learning goals and } \\
\text { understandings through } \\
\text { application of subject matter. }\end{array}$ & $\begin{array}{l}\text { Performance tasks are } \\
\text { described that somewhat } \\
\text { ensure students are making } \\
\text { progress toward learning goals } \\
\text { and understandings through } \\
\text { application of subject matter. }\end{array}$ & $\begin{array}{l}\text { Performance tasks are } \\
\text { described that ensure } \\
\text { students are making } \\
\text { progress toward learning } \\
\text { goals and understandings } \\
\text { through application of } \\
\text { subject matter. }\end{array}$ & \\
\hline $\begin{array}{l}\text { Apply content area literacy } \\
\text { strategies before reading to } \\
\text { activate prior knowledge and/ } \\
\text { or set purpose for learning, } \\
\text { during learning, and in } \\
\text { reflecting on inquiry-based } \\
\text { learning in the targeted } \\
\text { discipline. }\end{array}$ & $\begin{array}{l}\text { The candidate does not } \\
\text { apply content area literacy } \\
\text { strategies. }\end{array}$ & $\begin{array}{l}\text { The candidate identifies } \\
\text { and applies at least two } \\
\text { content area literacy strategy } \\
\text { that supports student } \\
\text { understanding. }\end{array}$ & $\begin{array}{l}\text { The candidate identifies } \\
\text { and applies several content } \\
\text { area literacy strategies } \\
\text { that supports student } \\
\text { understanding. }\end{array}$ & \\
\hline $\begin{array}{l}\text { Reflect on inquiry-based } \\
\text { disciplinary literacy } \\
\text { planning. }\end{array}$ & $\begin{array}{l}\text { Reflections are incomplete } \\
\text { and do not address the } \\
\text { guidelines and prompts } \\
\text { provided in the lesson cycle } \\
\text { template. }\end{array}$ & $\begin{array}{l}\text { All reflections are complete } \\
\text { but only somewhat address } \\
\text { the guidelines and prompts } \\
\text { provided in the lesson cycle } \\
\text { template. }\end{array}$ & $\begin{array}{l}\text { All reflections are complete } \\
\text { and fully address the } \\
\text { guidelines and prompts } \\
\text { provided in the lesson cycle } \\
\text { template. }\end{array}$ & \\
\hline
\end{tabular}

members. Pre-service teachers were encouraged to follow up with OPC peers if they needed clarification or wanted additional support in their peer feedback. Note that peer review was included in the final lesson cycle rubric to encourage thoughtful and extensive feedback. Feedback was evaluated on how effectively pre-service teachers supported their rubric ratings with comments justifying their rating. We provide Table 4 as a sample timeline for the complete peer review/lesson cycle process.

We emphasize that this course was most students' first experience with planning for elementary disciplinary literacy. Thus, the content advice they offered to one another in the OPC, particularly for the first two lesson cycles while they were engaged in content learning for the course, was not always appropriate. However, this consideration was planned for when developing the lesson cycle project, and instructor also provided feedback to pre-service teachers in the OPC, based on their peer reviews. The purpose of this feedback was two-fold and: (a) provided opportunities for instructor to model how to 
Table 4. Peer Review/Lesson Cycle Timeline

\begin{tabular}{|l|l|}
\hline \multicolumn{1}{|c|}{ Date } & \\
\hline $1 / 22-1 / 26$ & Peer review instruction and practice \\
\hline $1 / 29-2 / 22$ & Instructor provides feedback on peer review practice \\
\hline $2 / 12$ & Submit lesson cycle draft to OPC \\
\hline $2 / 15$ & Complete peer review of each group member's lesson cycle draft \\
\hline $2 / 19$ & Submit final lesson cycle for grading \\
\hline
\end{tabular}

mitigate conflicting feedback from multiple peers; and (b) served to correct or better expand on feedback that might conflict with disciplinary literacy planning.

\section{Data Sources \& Analysis}

To understand pre-service teachers' perceptions of peer review through OPCs, the researchers collected multiple types of data. First, primary data directly related to perceptions, specifically reflection data within lesson cycles, post-project written formal reflection, and post-project semi-structured phone interviews, were collected. Also, student artifacts associated with the four lesson cycles, including the lesson cycle drafts, peer review rubrics, and lesson cycles were collected as secondary data to triangulate perception-focused data. These data allowed the researchers to understand how participants' perceptions aligned with their actual planning.

Researchers analyzed perception-focused primary data using a constant comparative method (Glaser \& Strauss, 1967), which consisted of a linear process of (a) open coding of data, (b) writing memos during coding to define relationships among codes, (c) creating concepts from collections of codes of similar content, and (d) defining categories of groups of similar concepts to determine similarities and differences in data. Concepts were then triangulated with secondary data to determine themes to understand how perceptions related to lesson planning for elementary disciplinary literacy. PSTs were provided transcripts of post-project phone interviews to member check for accuracy. No participants requested clarification or changes to be made to the transcripts.

\section{RESULTS}

Results of this study suggest that students enrolled in an asynchronous online course who participate in peer review through OPCs may benefit from the support and suggestions provided by their peers when refining disciplinary literacy lessons. Similarly, students may gain a better understanding of disciplinary literacy after participating in lesson cycles including peer review and reflection. Additionally, the use of OPCs for peer review may promote exposure to different experiences, ideas, and pedagogies leading to better understanding and planning for disciplinary literacy lessons. 


\section{Extended Reflection}

Although the lesson cycle template prompted a formal reflection of specific items multiple times during planning for disciplinary literacy, results indicated that participants were encouraged to extend reflection in both collaborative and independent ways beyond what was required while engaging in peer review in the OPC, and they valued both forms of this extended reflection. This reflection took place when participants were considering peer feedback as well as when they were reviewing peers' lesson cycles, both in ways that were particular to the OPC.

When considering peers' feedback, participants noted the discussion-board focused elements of the OPC encouraged collaborative online conversations reflecting on principles of disciplinary literacy and how they might be integrated in elementary planning. Stella (this and all names are pseudonyms) explained:

I appreciate and feel support with qualitative feedback, when people not only comment approve or disapprove [in the peer review rubric], but also when they go back through my lesson and pull examples out and say "you know this is why it could be stronger or this is why I think it is great because you did this" on the discussion board (Phone interview).

These conversations were often critical and prompted participants to ask for clarification on topics, such as how essential questions drive disciplinary literacy and what authentic assessments might promote disciplinary literacy. Janene candidly explained,

Oh, I liked that my classmates responded to me thoroughly in the rubric and on the discussion board. Even if it [sic] was negative comments, it helped me know that I needed to step my game up! And they gave me suggestions to on what I needed to improve on. It was very helpful having the peer review. It helped me to revise and reflect on my lesson plan and make it better (Phone interview).

To illustrate, one of Janene's OPC members, Anna, posted a peer review rubric for Janene to review and also added a thread that sparked a group discussion between Janene, Anna, and their third group member, Leah:

Anna: I've attached your peer review, and I enjoyed reading what you planned! One thing I really noticed was that you worked hard on your essential questions, but I'm not sure that we really need four questions. I think just one or two would be stronger. Does anyone know if there's a minimum?

Leah: I don't think there's a minimum, but the module on essential questions talks about having fewer (like two max) questions that really encompass what you want students to focus on.

Janene: Yeah, I wasn't sure about that either. I always think more is better! Which do you think were stronger.

Anna: One and three were the strongest. I'm not sure two and four were really essential questions because they focus on specific facts and not concepts of learning. 
Leah: I agree with Anna! I'm going to go back to look at mine to see if they're fact-focused or conceptfocused. Thanks, Anna!

This extended reflection through discussion was a positive feature of the OPCs for peer review and provided indirect opportunities for pre-service teachers to continue to reflect on both the completed peer review rubrics and discussion board conversations about planning.

These clarifying discussion-board conversations supported participants' independent reflection on whether or not their planning supported a disciplinary approach to literacy in elementary grades and if this approach was appropriate for their targeted grade level. Kirsten discussed this in her final written reflection:

As the semester went on, I was willing to try more new methods in my lesson cycles and got excited by the idea of using them in a future classroom. I was still anxious as I would sit down to write my lesson cycles, but that that anxiousness was helped by the discussion board and getting feedback from my classmates on whether or not I was on the right track.

As Kirsten indicated, the OPCs provided a tertiary space for reflection, outside of the lesson cycle template and final reflections, that promoted on-going consideration of planning for disciplinary literacy while pre-service teachers constructed lessons.

\section{Appreciation of Critical Feedback through Multiple Perspectives}

Participants in this study noted that the particular benefit of working with classmates in an online space that supported critical peer feedback was particularly appealing. The online course promoted open and constructive critique during the peer review process and participants were graded on their feedback to one another. Participants indicated appreciation of this critique, and they valued their classmates' different perspectives offered through the peer review process. Leah reflected, "No matter how well you think you have prepared a lesson, it can always be improved. My fellow teachers bring with them diverse backgrounds and experiences, all of which has value and was much appreciated" (Phone interview). Diversity in experiences was common in pre-service teachers' perceived experiences in the OPC, and was always discussed as a highlight. Ellie noted that some of the pre-service teachers in her OPC were working as substitute teachers during the certification process, and the "various experiences brought to the peer review by students who had teaching experience was one of the most useful tools from the course" (Written reflection).

Participants noted the challenge in regarding different perspectives in peer reviews, but they ultimately were able to read across reviews to make more informed decisions about revisions to their planning. Anna explained,

Sometimes it was a challenge to get multiple reviews that seemed to say different things. However, I learned upon closer reading that often those were just different ways of saying the same thing and the different perspectives offered by my group members helped me to create the best final lesson that I could. I definitely had to incorporate some cross-reading strategies, which we actually learned about in this course, and that made even deeper connections for me to the class content. (Written reflection) 
Further, participants seemed to value that the OPC was a safe space to gain feedback from a variety of pre-service teachers with different backgrounds. Alyece reflected:

I am honestly pretty shy I guess for a lack of a better word when it comes to letting other people read my lesson plans because I am my worse [sic] critic. But it was interesting to hear other people's thoughts in a professional space where the goal was to improve each other's work, and a lot of classmates with different experiences gave helpful advice on what they would use or what they thought I could include... to promote literacy within all subjects, not just language arts. (Phone interview)

Also, participants' planning for disciplinary literacy was bolstered when similar strengths were indicated across reviews. Kirsten particularly noted, "It was exciting toward the end of the semester to start getting similar peer reviews that appreciated the same components of the lesson I planned. That made me feel like I had really internalized all of the collective feedback I received while planning for disciplinary literacy" (Written reflection). Multiple perspectives seemed to somewhat alleviate concerns when participants were uncertain of their planning decisions, as Stella reflected, "I was sometimes uncertain if a strategy really fit with disciplinary literacy, but if the group was in agreement, I felt like I had made the right decision in my planning" (Written reflection). In short, if multiple peers indicated that a planning decision was positive, participants more confident in that decision. Yet, pre-service teachers still perceived challenges regarding peer review in the OPC, which are discussed in the following subsection.

\section{Challenge of OPC Peer Review in Online Coursework}

Despite the perceived benefits of the peer review process, participants struggled with valuing peer review in the OPC as a critical part of the lesson planning process. Specifically, participants placed value in online learning as a flexible and "less-interactive" (Janene, Written reflection) space where they could quickly complete assignments to suit their personal schedules. The structure of the peer review process somewhat limited participants perceived flexibility in that multiple deadlines (i.e., submitting drafts, posting completed peer review rubrics, and replying to feedback) and waiting on peer feedback required them to revisit Blackboard multiple times a week. Stella explained, "The most challenging part [of the course] was waiting for reviews. So, you're waiting to receive someone's work and constantly checking that because you want to make sure that you give them timely feedback. I am sure on the other side they are waiting for my feedback" (Phone interview).

Aligning with this challenge, there was consensus that the primary reason participants opted to take an online course was that they had jobs and families outside of school. Ellie explained in her phone interview:

My experience [in the OPC] was good. But it is always difficult to get people to want to review your work because we are all so busy. So, no matter what, no matter how it is designed, I am afraid you are always going to have somebody who just wants to check that box off. I am just afraid that is how most people do it. I'm even speaking for myself. It isn't that I didn't care, but I need to get mine done. I have things to do. I have kids to feed. So, sometimes it was just checking the box.

Indeed, the peer review component of the OPCs required higher and more frequent participation in an online course as the OPC was designed to encourage continuous community of learning throughout the semester. While this OPC characteristic is often found to be a positive feature, particularly in profes- 
sional development settings with in-service teachers, the particular setting of this course consisting of pre-service teachers still taking degree coursework diminished this feature as participants found frequent participation and engagement to be somewhat tedious. The participants' collective experiences with online learning seemed to consist of bi-monthly or monthly deadlines that were more convenient. As Aleyce wrote in her final reflection:

Admittedly, even with everything I learned in this course, the structure was very difficult for most adults. I have never taken an online course where we had to turn in work every week, and particularly where we had to do a peer review process over multiple Blackboard sessions the weeks when our lesson cycles were due. I learned a lot, and peer review was beneficial, but it was hard for me to keep up and value that part of the course.

Further, due to participants' lack of experience with disciplinary literacy, results indicated that they perceived feedback from the instructor to be more valuable and peer review did not ensure maximum benefit to final lesson cycle grades. Leah discussed:

I would take [peer's] advice on my general overall topic from my rough draft and think about it in my final revisions. But, I would really take my professor's feedback from my submitted lesson cycles and use that feedback for future [lesson cycles]. So, I would actually just take the exact lesson cycle that I got a 100 on and I would just use exactly what I did except with a different lesson cycle so I knew that it was set up for success. At the end of the day, I want to make the best grade possible, and the professor's feedback was the most useful for that, because I don't think any of us were really knowledgeable about disciplinary literacy, especially in the beginning (Phone interview).

However, as the semester progressed and participants felt more comfortable in their OPCs, they began to more critically consider peer feedback, use that feedback, and the instructor's feedback, to strengthen their final lesson cycles. For example, Stella ended her phone interview by explaining,

By the way, I did like the [lesson cycle] rubrics better than a checklist. With the rubrics, you actually compare what the teacher is looking for because the rubrics aligned with the rubric she graded with. You can also read through the activity, whatever [your peer] created, and then go back and look at specific parts to make sure they are linking content and they are pushing past the classroom into the real world.

Janene echoed Stella by explaining, "The peer review was a little tedious and I wasn't always sure about the advice I was giving or receiving. But, I got better at discerning good feedback because of the peer review rubric structure, and I think the process made my lessons stronger" (Written reflection). Thus, even with the challenges peer review in the OPC presented, participants' overall reflections and perspectives indicated the process was effective and useful, although it was a different experience from previous online coursework. 


\section{DISCUSSION}

In-service and pre-service teachers alike may draw on what they have learned from others when sharing resources, asking questions, and reflecting on instruction in OPCs (Beach, 2012). However, research suggests that more formal OPCs, such as the one required for this course, may need to be highly structured (Charalambos, Michalinos, \& Chamberlain, 2004), at least in preliminary stages, to be optimally beneficial. Pre-service teachers in this study were required to reflect on specific areas in the lesson cycle template while creating instruction and post-project in formal writing. Although pre-service teachers in this study both appreciated and were able to improve their planning based on the multiple reflection opportunities presented in the peer review process through the OPC, this consideration also seemed to be a challenge. Citing work and time-focused factors, participants in this study indicated preference for loosely-structured OPCs they could engage in less often. Many members of the OPC valued the less structured, informal reflection made available through asynchronous discussion for clarification and idea-offerings. Nevertheless, this level of collaborative reflection is a unique opportunity in online education to, in many ways, mimic positive attributes of face-to-face instructional settings where students can speak directly and hash out ideas with interactive discussion.

Consequently, most course members and all participants completed the requisite peer reviews and their lesson cycle score and qualitative feedback indicated the benefit of peer review in OPCs. However, as perspectives are important to consider in teacher education (Anders et al., 2000; Richardson, 1996), teacher educators must consider techniques that not only benefit students but that appeal to their learning so that they continue to consider literacy, and specifically disciplinary literacy, in their future instruction.

Blintz (2013) noted that those new to OPCs may become overwhelmed with the amount of information available, either in the form of additional resources or information received from other members. Yet, pre-service teachers' perceptions indicated they appreciated it when a peer remarked that a plan, for example, needed improvement and clarification based on what that peer was currently experiencing in their substitute teaching or fieldwork for other courses. As pre-service teachers brought their own experiences to peer review in the OPC, they were provided a window into what others, not just the instructor, knew about elementary contexts and planning for disciplinary literacy in those contexts. At the same time, pre-service teachers perceived the diversity of their OPC members' experiences and backgrounds to be useful in designing plans for elementary disciplinary literacy. They acknowledged that they had to engage in even deeper reflection to consider peers' feedback and why they offered the suggestions they did.

Often, in online asynchronous courses, the instructor's feedback is all students are offered, which suggests the benefit of peer review in OPCs in this type of course setting. Further, considering multiple peer reviews encouraged pre-service teachers to corroborate feedback, which allowed them to accept or reject feedback based on their understandings of disciplinary literacy. These understandings were in flux for the majority of the course as pre-service teachers discussed planning together in the OPCs and built their understandings collaboratively, suggesting a potential benefit of peer review in OPCs that supported a number of perspectives and educational experiences. The multiple sources of feedback that pre-service teachers had to attend to in this study, as well as their peers' varying levels of disciplinary literacy understanding, may have been taxing to work through and might also contribute to their slight frustration in the peer review process. This finding highlights the need to support teachers in reading across reviews to aid in management of multiple sources of feedback. 
Moreover, OPCs may act as cohorts for pre-service teachers to create structural support and the development of professional relationships (Wray, 2007) but with the benefit of working at a convenient time. The opportunities for collaborative learning and exchange of ideas provided through OPCs may result in shared leadership, vision, shared personal practice, and supportive conditions (Colak, 2017). This study considered these opportunities and how teacher educators can structure review-focused OPCs to best benefit, support, and engage pre-service teachers.

Indeed, time and membership have been cited as both benefits and challenges to participation in OPCs (Bandy, 2019). Members of OPCs have the benefit of accessing resources and information on a schedule that they find beneficial. However, it takes time to build trusting online relationships with community partners and to wait for responses and resources from peers. This means that participants must have time management skills that may be practiced and utilized. Although the instructor limited the amount of peer reviews to be completed for each lesson cycle, pre-service teachers' previous experiences with limited interaction with the instructor and other class participants in asynchronous online environments may have influenced their perceptions of set schedules in this type of course. In light of these findings, the authors encourage teacher educators who use online instruction to dedicate more explicit instruction to the benefit of peer review in general and how OPCs can support professional development. Further, even though pre-service teachers were somewhat concerned by the schedule set forth in peer review, they noted that the schedule was necessary to provide timely and consistent feedback. Thus, teacher educators might consider fewer rounds of peer review with more time provided in between rounds for increased flexibility in online asynchronous learning.

\section{IMPLICATIONS FOR TEACHER EDUCATION AND RESEARCH}

ILA standard 2.1 (2017) requires teacher candidates "use foundational knowledge to design, select, critique, adapt, and evaluate evidence-based literacy curricula that meet the needs of all learners." The inclusion of OPCs in teacher education has the potential to improve learning and instructional design and provide a professional network and set of skills that can be used throughout future teaching careers (Duncan-Howell, 2010). Members in this OPC had the potential to learn from others in their field while contributing different perspectives and resources on disciplinary literacy planning. Those who participate in OPCs may be more willing to help others solve problems, share resources, and give and receive emotional support from other members (Tseng \& Kuo,2014), an important part of collaborative and successful planning for literacy.

Similarly, teaching, although thought of as a social institution, can be isolating and those involved often look for supportive communities of likeminded professionals. OPCs provide an opportunity for students to interact and build a bond between their peers and the instructor that may not have otherwise happened, especially in an online learning setting (Hou, 2015). Additionally, members of OPCs have the flexibility to create their own meeting schedules or to work on individually (NRC, 2007), a benefit for pre-service teachers juggling coursework but who need to be held accountable.

Of course, for one to fully benefit from membership in an OPC, the participant needs to actively commit to a culture of collaboration and trust (Duncan-Howell, 2010; Matzat, 2013). Furthermore, educators working with pre-service teachers should help justify the decision to participate in an OPC, particularly in peer review. When membership in an OPC is encouraged instead of mandated, there may be more buy in and belief that it is time well-spent. Many find that they have limited time to devote to OPC on an 
individual basis or that there is a lack support from administrators and those in higher education (NRC, 2007). However, pre-service teachers in this study had holistically positive experiences of peer review in the OPC, which helped to mitigate some of the challenges they faced with challenges focused on time and structure. The aim of using the OPC in this study was to potentially jumpstart future teachers' awareness of the value of online professional communities to support planning for literacy instruction, and to an extent, this course seemed to promote that awareness. Results indicated multiple benefits from this aim but also suggested areas for continued consideration.

In conclusion, this study suggests that peer review in OPCs in an asynchronous online course may be beneficial to supporting pre-service teachers' refinement of disciplinary literacy lessons and ideas about disciplinary literacy. OPCs may promote various levels of reflection and exposure to a variety of backgrounds and experience with classroom instruction, which was a positive feature of peer review in OPCs. Future research might consider how more strategic grouping to connect PSTs with similar teaching experience may influence OPCs. Additionally, although outside factors such as prior experience with online learning and out-of-school lives may influence how pre-service teachers perceive peer review, pre-service teachers' instruction may ultimately benefit from participation in OPCs, and teacher educators should plan multiple methods for approaching and structuring these environments to support disciplinary literacy instruction in elementary grades. Further, researchers may examine varying levels of instructor involvement in OPCs to guide optimal instruction in peer review in disciplinary literacy planning. Such research directions may serve to further enhance online instruction in literacy-focused teacher education.

\section{REFERENCES}

Anders, P. L., Hoffman, J., \& Duffy, G. G. (2000). Teaching teachers to teach reading: Paradigm shifts, persistent problems, and challenges. In M. L. Kamil, P. B. Mosenthal, P. D. Pearson, \& R. Barr (Eds.), Handbook of reading research (Vol. 3, pp. 251-267). Mahwah, NJ: Lawrence Erlbaum.

Bandy, J. (2019). Challenges and opportunities of community engaged teaching. Retrieved from https:// wp0.vanderbilt.edu/cft/guides-sub-pages/challenges-and-opportunities-of-community-engaged-teaching/

Beach, R. (2012). Can online learning communities foster professional development? Language Arts, $89(4), 256-262$.

Blitz, L. (2013). Can online learning communities achieve the goals of traditional professional learning communities? What the literature says. Retrieved from https://files.eric.ed.gov/fulltext/ED544210.pdf

Bond, N. (2013). Developing a professional learning community among pre-service teachers. Current Issues in Education, 16(2), 1-15.

Boud, D., Cohen, R., \& Sampson, J. (2001). Peer learning in higher education: Learning from and with each other. New York, NY: Routledge.

Brock, C. H., Goatley, V. J., Raphael, T. E., Trost-Shahata, E., \& Weber, C. M. (2014). Engaging students in disciplinary literacy, $K-6$. New York, NY: Teachers College Press. 
Cappello, M., \& Lafferty, K. E. (2015). The roles of photography for developing literacy across the disciplines. The Reading Teacher, 69(3), 287-295. doi:10.1002/trtr.1418

Charalambos, V., Michalinos, Z., \& Chamberlain, R. (2004). The Design of Online Learning Communities: Critical Issues. Educational Media International, 41(2), 135-143. doi:10.1080/09523980410001678593

Çolak, E. (2017). Teachers experiences in a professional learning community on the constructivist lesson planning: Acase study among primary school teachers. Ted Eğitim Ve Bilim; doi:10.15390/eb.2017.6911

Colwell, J. (2012). Using a collaborative blog project to introduce disciplinary-literacy strategies in social studies pre-service teacher education. Journal of School Connections, 4(1), 25-52.

Colwell, J. (2016). Examining pre-service teachers' beliefs about disciplinary literacy in history through a blog project. Action in Teacher Education, 38(1), 34-48. doi:10.1080/01626620.2015.1118414

Colwell, J., \& Hutchison, A.C. (2018). Considering a Twitter-based professional learning network in literacy education. Literacy Research \& Instruction, 57(1), 5-25.

Darling-Hammond, L., \& Richardson, N. (2009). Research review / teacher learning: What matters? How Teachers Learn, 66(5), 46-53.

Duncan-Howell, J. (2010). Teachers making connections: Online communities as a source of professional learning. British Journal of Educational Technology, 41(2), 324-340. doi:10.1111/j.14678535.2009.00953.x

Glaser, B., \& Strauss, A. (1967). The discovery of grounded theory. Chicago: Aldine.

Gritter, K. (2010). Insert student here: Why content area constructions of literacy matter for pre-service teachers. Reading Horizons, 50(3), 147-168.

Håland, A. (2016). Disciplinary literacy in elementary school: How a struggling student positions herself as a writer. The Reading Teacher, 70(4), 457-468. doi:10.1002/trtr.1541

Hobbs, R., \& Coiro, J. (2016). Everyone Learns from Everyone. Journal of Adolescent \& Adult Literacy, 59(6), 623-629. doi:10.1002/jaal.502

Hou, H. (2015). What makes an online community of practice work? A situated study of Chinese student teachers' perceptions of online professional learning. Teaching and Teacher Education, 46, 6-16. doi:10.1016/j.tate.2014.10.005

International Literacy Association (ILA). (2018). Standards for the preparation of literacy professionals 2017. Newark, DE: Author.

Juel, C., Hebard, H., Haubner, J. P., \& Moran, M. (2010). Reading through a disciplinary lens. Educational Leadership, 67(6), 12-17.

Lock, J. V. (2006). A New Image: Online Communities to Facilitate Teacher Professional Development. Journal of Technology and Teacher Education, 14(4), 663-678. Retrieved May 21, 2019 from https:// www.learntechlib.org/primary/p/21030/ 
Mackey, J., \& Evans, T. (2011). Interconnecting networks of practice for professional learning. The International Review of Research in Open and Distributed Learning, 12(3), 1. doi:10.19173/irrodl.v12i3.873

Maheady, L., Smith, C., \& Jabot, M. (2013). Utilizing Evidence-Based Practice in Teacher Preparation. In B. G. Cook, M. Tankersley, \& T. J. Landrum (Eds.), Evidence-Based Practices: Advances in Learning and Behavioral Disabilities (Vol. 26, pp. 121-147). Emerald Group Publishing Limited. doi:10.1108/ S0735-004X(2013)0000026008

Matzat, U. (2013). Do blended virtual learning communities enhance teachers' professional development more than purely virtual ones? A large-scale empirical comparison. Computers \& Education, 60(1), 40-51. doi:10.1016/j.compedu.2012.08.006

McConnell, T. J., Parker, J. M., Eberhardt, J., Koehler, M. J., \& Lundeberg, M. A. (2012). Virtual Professional Learning Communities: Teachers' Perceptions of Virtual Versus Face-to-Face Professional Development. Journal of Science Education and Technology, 22(3), 267-277. doi:10.100710956-012-9391-y

Moje, E. B. (2008). Foregrounding the disciplines in secondary literacy teaching and learning: A call for change. Journal of Adolescent \& Adult Literacy, 52(2), 96-107. doi:10.1598/JAAL.52.2.1

Moore, C., \& Teather, S. (2013). Engaging students in peer review: Feedback as learning. Issues in Educational Research, 23(2), 196-212.

National Research Council (NRC). (2007). Enhancing Professional Development for Teachers: Potential Uses of Information Technology: Report of a Workshop. Washington, DC: The National Academies Press. doi:10.17226/11995

Park, J. Y. (2013). All the ways of reading literature: Pre-service English teachers' perspectives on disciplinary literacy. English Education, 45(4), 361-384.

Pytash, K. E. (2011/2012). Teaching PSTS to take a disciplinary approach to teaching writing. Journal of Content Area Reading, 9(1), 105-122.

Richardson, V. (1996). The role of attitudes and beliefs in learning to teach. In J. Sikula (Ed.), Handbook of research in teacher education (2nd ed.; pp. 102-119). New York: Macmillan.

Scheeler, M., Budin, S., \& Markelz, A. (2016). The role of teacher preparation in promoting evidencebased practice in schools. Learning Disabilities (Weston, Mass.), 14(2), 171-187.

Shanahan, C., \& Shanahan, T. (2014). Does disciplinary literacy have a place in elementary school? The Reading Teacher, 67(8), 636-639. doi:10.1002/trtr.1257

Shanahan, T., \& Shanahan, C. (2008). Teaching disciplinary literacy to adolescents: Rethinking contentarea literacy. Harvard Educational Review, 78(1), 40-61. doi:10.17763/haer.78.1.v62444321p602101

Sim, C. (2006). Preparing for professional experiences-Incorporating pre-service teachers as 'communities of practice'. Teaching and Teacher Education, 22(1), 77-83. doi:10.1016/j.tate.2005.07.006

Strasma, K. (2009). Spotlighting: Peer-response in digitally supported first-year writing courses. Teaching English in the Two-Year College, 37(2), 153-160. 
Tseng, F., \& Kuo, F. (2014). A study of social participation and knowledge sharing in the teachers online professional community of practice. Computers \& Education, 72, 37-47. doi:10.1016/j.compedu.2013.10.005

Willis, J., \& Cifuentes, L. (2005). Training Teachers to Integrate Technology into the Classroom Curriculum: Online versus Face-to-Face Course Delivery. Journal of Technology and Teacher Education, 13(1).

Wray, S. (2007). Teaching portfolios, community, and pre-service teachers' professional development. Teaching and Teacher Education, 23(7), 1139-1152. doi:10.1016/j.tate.2006.10.004

Wright, N. (2010). Twittering in teacher education: Reflecting on practicum experiences. Open Learning, 25(3), 259-265. doi:10.1080/02680513.2010.512102

Wright, T. S., \& Gotwals, A. W. (2017). Supporting disciplinary talk from the start of school: Teaching students to think and talk like scientists. The Reading Teacher, 71(2), 189-197. doi:10.1002/trtr.1602

Yin, R. (2018). Case study research and applications: Design and methods (6th ed.). Thousand Oaks, CA: Sage.

\section{ADDITIONAL READINGS}

Baker-Doyle, K. J. (2011). The networked teacher: How new teachers build social networks for professional support. New York: Teachers College Press.

Gunawardena, C. N., Hermans, M. B., Sanchez, D., Richmond, C., Bohley, M., \& Tuttle, R. (2009). A theoretical framework for building online communities of practice with social networking tools. Educational Media International, 46(1), 3-16. doi:10.1080/09523980802588626

Hynd-Shanahan, C. (2013). What does it take?: The challenge of disciplinary literacy. Journal of Adolescent \& Adult Literacy, 57(2), 93-98. doi:10.1002/JAAL.226

King, K. P. (2011). Professional learning in unlikely spaces: Social media and virtual communities as professional development. International Journal of Emerging Technologies in Learning, 6(4), 40-46. doi:10.3991/ijet.v6i4.1765

Kist, W. (2008). "I gave up my space for Lent": New teachers and social networking sites. Journal of Adolescent \& Adult Literacy, 52(3), 245-247. doi:10.1598/JAAL.52.3.7

Ranieri, M., Manca, S., \& Fini, A. (2012). Why (and how) do teachers engage in social networks? An exploratory study of professional use of Facebook and its implications for lifelong learning. British Journal of Educational Technology, 43(5), 754-769. doi:10.1111/j.1467-8535.2012.01356.x

Reich, J., Levinson, M., \& Johnston, W. (2011). Using online social networks to foster preservice teachers' membership in a networked community of praxis. Contemporary Issues in Technology \& Teacher Education, 11(4), 382-397.

Trust, T. (2012). Professional learning networks designed for teacher learning. Journal of Digital Learning in Teacher Education, 28(4), 133-138. doi:10.1080/21532974.2012.10784693 


\section{KEY TERMS AND DEFINITIONS}

Case Study: An approach to organizing research to intensely study and consider a particular person, group, or system.

Disciplinary Literacy: A perspective that focuses on literacy as the specific expert practices and skills a person needs to study in a specific subject area, such as English, history, mathematics, or science.

Feedback: The suggestions, comments, and questions provided to improve a person's performance or thinking.

Lesson Cycle: A structured approach to planning that prompts a series of instructional decisions and reflection on these decisions to create thoughtful and well-crafted lessons.

Online Professional Community: A group of individuals who come together in an online space to discuss a shared professional idea, collaborate, exchange resources, and provide feedback to one another.

Peer-Review: A collaborative process in which peers within a group or class review and critique each other's work and provide written or verbal feedback for improvement.

Pre-Service Teacher Education: An area of education that focuses on teacher training for college or university students who are preparing to become classroom teachers but who are not yet certified to teach. 


\section{APPENDIX A}

\section{Table 5. Lesson Cycle Template}

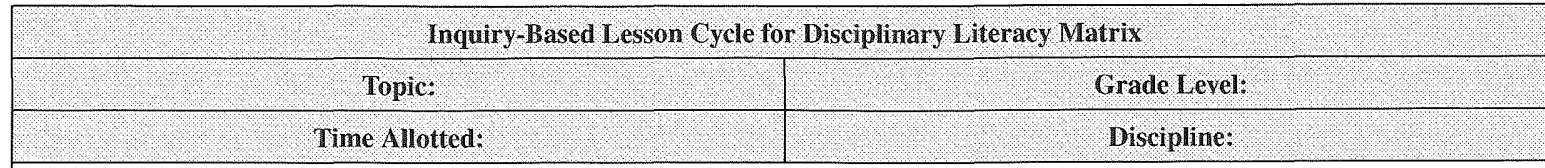

Rationale: Discuss in 2-3 paragraphs reasons you selected this topic and how inquiry could support learning and understanding in this discipline. Specifically discuss how this topic will promote disciplinary literacy. What challenges or obstacles to you foresee in teaching this lesson?

Preparation for Obstacles: Describe how you might prepare for challenges or obstacles that you may face in teaching this topic from an inquiry-based disciplinary literacy standpoint?

\section{Phase I: Identify Desired Results}

Disciplinary Practices Targeted: Bullet list the disciplinary practices students will use in this lesson to engage in disciplinary learning. Cite how you know these are disciplinary practices.

Texts Required: Bullet list the texts that students will learn from or create in this lesson to engage in disciplinary learning. At least one of these texts should be non-print source (e.g, not a textbook or piece of prose-based literature). Consider what digital tools might be useful in scaffolding or supporting students' reading and understanding in your lesson.

Then, discuss in one paragraph how these texts support diverse learners and a culturally responsive curriculum. Remember, texts, from a disciplinary literacy standpoint, are anything that can be read and understood (i.e., songs, maps, speeches, body language, online resources, as well as traditional print-based texts)

\section{Understandings:}

What should students hear, read, view, explore, or otherwise encounter to promote disciplinary literacy?

What disciplinary knowledge and skills should students master?

What is important for them to know and be able to do?

What big ideas and important disciplinary understandings should students retain?

Essential Questions: State questions that will frame and guide disciplinary instruction. These should be open-ended questions that cannot be answered with finality in one sentence. Responses to these questions should prompt further inquiry and learning in the discipline. EQs should not be easily answered with textbook information. These questions should frame the broad goals of your lesson and provide a target for students to address in their inquiry-based learning. Multiple responses may appropriately and correctly answer an EQ. (e.g., Why do leaves change color?)

Reflection: Revisit the disciplinary practices targeted, the texts you've selected, understandings, and your EQs. Reflect in one-two paragraphs on their alignment. Do your texts and understandings promote the disciplinary practices you are targeting? Does your EQ support the understandings you want students to gain from this lesson?

\section{Phase II: Determine Acceptable Evidence}

Performance Task(s):

Describe the authentic tasks students will engage in to determine if they are making progress toward your disciplinary learning goals of what they should know, understand, and be able to do.

\section{Other Evidence:}

List any other evidence here that are not performance tasks.

Reflection: Reflect in one paragraph on the performance tasks you've selected. How are these tasks authentic and used in everyday, outof-school life?

Phase UI: Plan Learning Experience \& Instruction

\section{Preparing Students for Literacy Learning}

Description of Activities/Methods/Materials: Provide description of your methods for preparing your students to engage in disciplinary learning about the topic. Describe the resources and materials you will need, activities students will engage in, how you will arrange students for these activities (e.g., grouping, etc.), and the literacy methods you will employ as a teacher to help students prepare.

Literacy Strategies Employed: What content literacy strategies will you integrate to prepare your students for disciplinary learning? 
Table 5. Continued

\begin{tabular}{|c|c|}
\hline \multicolumn{2}{|c|}{ Inquiry-Based Lesson Cycle for Disciplinary Literacy Matrix } \\
\hline $1: 01: 01: 0$ & Grade Level: \\
\hline 1. & Discipline: \\
\hline
\end{tabular}

Description of Activities/Methods/Materials: Provide description of your methods for assisting/guiding your students to engage in disciplinary learning about the topic. Describe the resources and materials you will need, activities students will engage in, how you will arrange students for these activities, and the literacy methods you will employ as a teacher to help guide/assist students.

Literacy Strategies Employed: What content literacy strategies will you integrate to assist your students for disciplinary learning?

Helping Students Engage in Reflection to Promote Literacy

Description of Activities/Methods: Provide description of your methods for helping students reflect on disciplinary learning about the topic. Describe the resources and materials you will need, activities students will engage in, how you will arrange students for these activities, and the literacy methods you will employ as a teacher to help students reflect.

Literacy Strategies Employed: What content literacy strategies will you integrate to help your students reflect on disciplinary learning?

Reflection: In three paragraphs, reflect on the activities and methods you listed above. Compare your activities and methods with Phases I and II.

- Do your methods support learning about the disciplinary practices and understandings you targeted? How so?

- Are the texts you selected supported by content literacy strategies so that students may gain independence in learning from these texts? How so?

- Do your methods and activities promote inquiry that helps students address and provide responses to the Essential Questions?

\section{Final Reflections/Considerations}

Reflection: Provide a 3 paragraph reflection on the following:

1) What ideas from the module's videos and readings did you consider or incorporate into the lesson cycle? How did you do so?

2) What ideas from the textbook did you consider or incorporate into the lesson cycle? How did you do so?

\section{APPENDIX B}

Figure 1. Sample Completed Peer Review Rubric

\begin{tabular}{|c|c|c|}
\hline indicator & Ratings: (Hlighlight the appropriane rating.) & Comments to Prer: \\
\hline \begin{tabular}{|l|} 
Develop essential \\
questions that frame \\
and guide instruction to \\
promote discovery and \\
inquiry through an open- \\
ended question.
\end{tabular} & 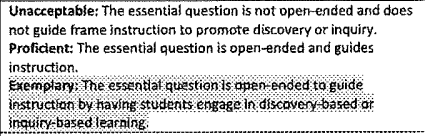 & 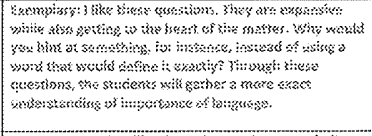 \\
\hline $\begin{array}{l}\text { Develop goals for } \\
\text { understandings that } \\
\text { focus on what } \\
\text { knowledge and skilis } \\
\text { students should master } \\
\text { and be able to do }\end{array}$ & 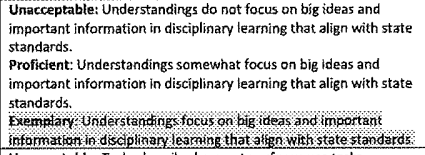 & 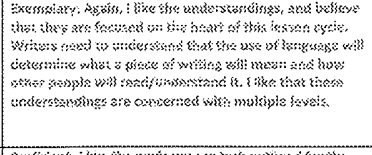 \\
\hline $\begin{array}{l}\text { Apply performance tasks } \\
\text { as assessments to } \\
\text { ensure students are } \\
\text { mazking progress toward } \\
\text { learning goals and } \\
\text { understandings. }\end{array}$ & 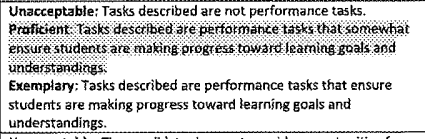 & 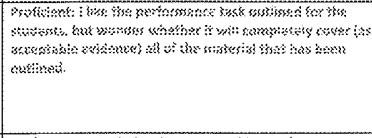 \\
\hline $\begin{array}{l}\text { Performance tasks } \\
\text { provide opportunities } \\
\text { for students to apply } \\
\text { subject matter by } \\
\text {-analyzing/maksng } \\
\text { inferences } \\
\text {-interpreting \& } \\
\text { evaluathg or } \\
\text {-synthesizing/ } \\
\text { transferring application }\end{array}$ & 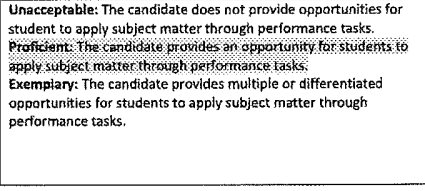 & 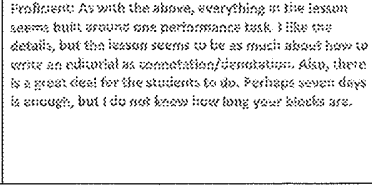 \\
\hline
\end{tabular}

